\title{
FEDERAL INCOME AND GIFT TAXATION OF MARITAL PROPERTY SETTLEMENTS
}

\begin{abstract}
$\mathrm{T}$ HE INCOME and gift taxation of property agreements entered into in contemplation of marriage or divorce ${ }^{1}$ must be ranked high on the list of federal tax inequities. Yet, this is not an area where it can be said that hard cases have made bad law. For in the really critical decisions, the courts were in a position to reach the most logical and practical result; they were neither restricted by precedent or rigid statutory language nor blinded by glaring economic realities. Although most of the pieces were fitted imto this particular puzzle more than a decade ago, perhaps it is not too late to protest against their aggregate pattern. It should be noted in considering the cases which make up this body of the law that most of the inequities spring from the refusal of the courts to accept the gift tax definition of "gift" when dealing with the income tax.
\end{abstract}

In Commissioner v. Mesta, ${ }^{2}$ decided in 1941, the husband had transferred stock greatly appreciated over its cost basis to his wife just before their divorce in consideration of her relinquishment of all claims for maintenance and support. The Commissioner assessed a deficiency in the husband's imcome tax on the theory that the difference between the basis of the stock in his hands and its fair market value at the time of the transfer was a taxable capital gain. The Court of Appeals for the Third Circuit curtly rejected the contention that a gift was involved ${ }^{3}$ and accepted the Commissioner's theory, relying heavily on the Supreme Court's language in Helvering v. Horst: ${ }^{4}$

The decisions and regulations have consistently recognized that receipt in cash or property is not the only characteristic of realization of income to a taxpayer. . . Where the taxpayer does not receive payment of income in money or property realization may occur when the last step is taken by which

\footnotetext{
${ }^{2}$ For recent discussions of the broader tax problems attending separation and divorce, see Rosenfield, Tax Problems from Marital Difficulties, 5 Prac. LAW. 63 (1959); Scharfy, Tax Problems Relating to Separation and Divorce, so W. REs. L. REV. 200 (1959).

\& ${ }_{123}$ F.2d 986 (3d Cir. 1941), cert. denied, 316 U.S. 695 reh. denied, 317 U.S. 704 (1942), 9 U. CH1. L. REv. 525 .

3 "Obviously the transfer was not a gift. ... Nor can it be treated as a division of property." 123 F.2d 986, 988.

"Ibid.
} 
he obtains the fruition of the economic gain which has already accrued to him.

The court denied that there was no way in which to measure the amount of income realized by Mesta from the transfer of the stock, holding that the value of the wife's rights would be presumed to be equal to the fair market value of the property transferred: ${ }^{5}$

... the amount of the taxpayer's obligation to his wife was fixed in part in terms of stock by the parties themselves who really dealt at arm's length with one another. ... We think that we may make the practical assumption that a man who spends money or gives property of a fixed value for an unliquidated claim is getting his money's worth.

Then, in r 945 , the Supreme Court, in Merrill v. Fahs, ${ }^{6}$ considered whether the transfer of property pursuant to an antenuptial agreement in exchange for the prospective bride's relinquishment of all marital rights in the transferor's estate was subject to the gift tax. Although the gift tax is silent on this specific point, a provision of the estate tax ${ }^{7}$ stipulates that a release of dower or curtesy or other marital rights in the transferor's estate is not adequate and full consideration to any extent. In a perfectly logical decision which has since been criticized with zeal, ${ }^{8}$ the Court held that the estate and gift taxes should be construed in pari materia in this respect. Accordingly, a gift tax was assessed on the property transferred.

The stage was set when, in 1947, the Court of Appeals for the Second Circuit decided Farid-es-Sultaneh v. Commissioner. ${ }^{9}$ In this case, the narrow question before the court was whether the taxable income realized upon the sale of stock earlier acquired pursuant to an antenuptial agreement should be measured by reference to the substituted basis of the transferor, as in a gift, or the fair market value of the stock at the time of transfer, as in a taxable sale or exchange. Thus, the broader, pivotal question was whether the relinquishment of dower and other marital rights in the estate of the transferor can constitute con-

\footnotetext{
${ }^{5} I b i d$.

324 U.S. 308 (1945), 19 TEMP. L.Q. 513 (1946). See also 36 Minn. L. REv. 918 ( 1952$)$.

'INT. REv. CODE OF $1954 \S 2043$ (b): "For purposes of this chapter, a relinquishment or promised relinquishment of dower or curtesy, or of a statutory estate created in lieu of dower or curtesy, or of other marital rights in the decedent's property or estate, shall not be considered to any extent a consideration 'in money or money's worth.' "'

${ }^{8}$ See Rand, What Is a Gift?, 34 Kx. L.J. 99 (1946).

I60 F.2d 812 (2d Cir. 1947). 47 ColUM. L. REv. 1073; 60 HARv. L. REv. 986; 2 I So. Calif. L. Rev. I16; 22 Tul. L. Rev. 344.
} 
sideration for income tax purposes. Since the stock had greatly appreciated in value over the transferor's basis when it was acquired by the taxpayer, she was naturally anxious that the transaction in which she received it be deemed to represent a bona fide exchange for income tax purposes.

The court found in the taxpayer's favor. Thus, although the income tax nowhere defines "gift," the statutory "adequate and full consideration" test applicable under the estate and gift taxes was rejected in favor of an essentially coinmon law test of consideration. ${ }^{10}$ Merrill v. Fahs was quickly dismissed: ${ }^{11}$

We find in this decision no indication, however, that the term "gift" as used in the income tax statute should be construed to include a transfer which, if made when the gift tax were effective, would be taxable to the transferor as a gift merely because of the special provisions in the gift tax statute defining and restricting consideration for gift tax purposes.

Meanwhile, cases such as Commissioner v. Maresi' and Commissioner v. Converse ${ }^{13}$ had established that no gift is made when marital rights are exchanged for property in a postnuptial arrangement contingent for its efficacy upon approval by the divorce court. The theory was that since, without the decree, there would be no enforceable rights and obligations, the transfer was not made pursuant to a "promise or agreement" in the statutory sense. ${ }^{14}$

A further refinement was added in 1950 by Harris v. Commissioner. ${ }^{15}$ There, the Supreme Court held that no gift was involved in

${ }^{30} I d$. at 815: "[Petitioner's] inchoate interest in the property of her affianced husband greatly exceeded the value of the stock transferred to her. It was a fair consideration under ordinary legal concepts of that term for the transfers of the stock by him."

The decision also raised donative intent as an element of a gift for purposes of the income tax: "Though such a consideration as this petitioner gave for the shares of stock she acquired from Mr. Kresge might not have relieved him from liability for a gift tax, ... it was nevertheless a fair consideration which prevented her taking the shares as a gift under the income tax law since it precluded the existence of a donative intent." Ibid.

${ }^{11} I d$. at $8 \times 4$.

${ }^{23} 156$ F.2d 929 (2d Cir. 1946).

${ }^{12}{ }_{163}$ F.2d 131 (2d Cir. 1947).

16 The requirement that the claim against the transferor be based. upon a "promise or agreement" stems from the fact that this language was included in INT. REv. CoDE of $1939 \S 8 \mathrm{I}_{2}$ (b), which was incorporated into the gift tax in Merrill v. Fahs. See INT. REV. CODE OF $1954 \S 205 \dot{3}(\mathrm{c})$.

${ }_{28} 340$ U.S. 106 (1950). See Pedrick, The Gift Tax Jurrisdiction of the Divorce Court, 46 Ind.'L. REv. 177 (195i); 'Comment, 3 DuKE B.J. I (1952), for discussion of the significance of this case.

$-1$. 
a postnuptial property settlement even though the provisions thereof were, if divorce in fact ensued, to outlive the provisions of the divorce decree. The Court reasoned, in effect, that since the gift tax is levied upon the transfer ${ }^{16}$ of property, there should be no gift tax where the transfer is "effected by court decree," since the decree would not, in a realistic sense, constitute a "promise or agreement" between the parties thereto.

Finally, section 2516 , written into the 1954 Code, ${ }^{18}$ provides that for purposes of the gift tax any transfer of property in settlement of marital rights which is incorporated into a written agreement followed by divorce within two years shall be deemed to be made for a full and adequate consideration.

The product of these developments is this: Where property is transferred for relinquishment of prospective marital rights in the transferor's estate pursuant to an antenuptial agreement, a gift tax liability is incurred under the Merrill rule. And, since this transfer is a sale or exchange for the wife under the rule of Farid-es-Sultaneh, it must also be a taxable event for the husband ${ }^{19}$ for income tax purposes. Similarly, a transfer of property for relinquishment of marital rights, other than support, ${ }^{20}$ pursuant to a postnuptial agreement which does not fall

${ }^{10}$ See INT. REv. CODE OF $1954 \$ 2501$ (a).

17340 U.S. I06, 111.

18 "Where husband and wife enter into a written agreement relative to their marital and property rights and divorce occurs within 2 years thereafter (whether or not such agreement is approved by the divorce decree), any transfers of property or interests in property made pursuant to such agreement-

(1) to either spouse in settlement of his or her marital or property rights, or

(2) to provide a reasonable allowance for the support of issue of the marriage during minority, shall be deemed to be transfers made for a full and adequate consideration in the money or money's worth."

Note that transfers to adult children, or to minor children, in excess of their needs for reasonable support are subject to the gift tax, whether or not they are made pursuant to divorce decree. Rosenthal v. Commissioner, 205 F.2d 505 (2d Cir. I953); Karl T. Wiedemann, 26 T.C. 565 (1956).

${ }^{10}$ The Farid-es-Sultaneh case, of course, did not consider the husband's income tax liability at all. Moreover, the Mesta case involved a postnuptial transfer. No case has been found wherein it was directly held that a transferor of property in an antenuptial settlement incurs an income tax liability. This seems, however, a logical inference to be drawn from the reasoning employed in both the Farid-es-Sultaneh and Mesta decisions.

${ }^{20}$ E.T. 19, 1946-2 CUM. BuLl. I66, specifically provides that the right of a divorced wife to support from a former husband during their joint lives shall not be considered an element of her marital rights in his property or estate for purposes of the gift tax. In ruling that a wife's right of support may constitute consideration for purposes of the estate and gift taxes, the Service relinquished the victory which it had won when 
within the purview of the Harris case or section 2516, attracts a gift tax. Commissioner v. Mesta and its progeny establish that a postnuptial settlement is not a gift for purposes of the income tax. ${ }^{21}$ Thus, in either an antenuptial or a postnuptial property settlement, even as a gift tax is imposed on the theory that the transfer was not for an adequate and full consideration in money or money's worth, an income tax may be incurred by the husband on the theory that the transfer was not a gift. Moreover, if either type of transfer is a taxable event under the income tax for one spouse, it must logically have the same significance for the other. That is, as to the wife, all logic would indicate that she realizes a gain to the extent that the value of what she receives exceeds her basis in the rights which she gives up.

It is no doubt true that the typical postnuptial property settlement represents a compromise of adverse interests at the conclusion of arm's length negotiations. And antenuptial settlements are often executed, after some hard bargaining, on the initiative of a man of some wealth who has had bitter experience upon the dissolution of a previous marriage. To this extent, these arrangements do resemble a taxable exchange little motivated by benevolent feelings. But this characterization is not entirely accurate. The transaction does not produce any "new" income. What occurs is either a voluntary or involuntary reallocation of capital within the family.

Moreover, the dilemma created by Farid-es-Sultaneh and related cases was in no wise inevitable ${ }^{22}$ since the income tax statute nowhere defines "gift." It would not seem that the purposes of that statute would be frustrated if these transfers were deemed immune from in come taxation. That is, taxation of the gain would merely be postponed if the transferee took a substituted basis. On the other hand, since the marital rights of a wife in her husband's estate are specifically included in his gross estate for purposes of the estate tax, the estate tax scheme could be subverted to a marked extent if an inter vivos transfer releasing those rights were permitted to escape the gift tax. ${ }^{23}$

the Second Circuit held that support rights were marital rights in a spouse's estate, which did not constitute consideration for transfer tax purposes. See Meyer's Estate v. Helvering, 1 ro F.2d 367 (2d Cir.), cert. denied, 3 10 U.S. 651 (1940).

${ }^{21}$ See, e.g., Commissioner v. Halliwell, ${ }_{3} 1$ F.2d 642 (2d Cir. 1942), cert. denied, 319 U.S. 741 (1943); Commissioner v. Patino, 13 T.C. 816 (1949), aff'd, 186 F.2d 962 (4th Cir. 1950); Edna W. Gardner Trust, 20 T.C. 885 (1953).

${ }^{22}$ See Pedrick, op. cit. supra note 15, at 195.

${ }^{22}$ See Lowndes \& Kramer, Federal Estate and Gift Taxation 740, 741 (1956).

But see note 32 infra. 
To the extent to which it is possible without straining the statutory language, it seems desirable to correlate the provisions of the federal income, estate, and gift taxes. And if it can be assumed that only one tax should be levied upon marital settlements, it would seem that it logically should be the gift tax. That is, it is suggested that the meaning of "gift" be equated in all three taxes by applying the statutory adequate and full consideration test to cases involving either antenuptial or postnuptial property settlements.

It may seem difficult to accept a definition of "gift" which does not turn upon donative intent. Yet, when working in a field such as taxation, no apology need be made for adopting that standard which will produce the most equitable result in tax matters, regardless of the ensuing damage to concepts imported from the common law. ${ }^{24}$ It is submitted that uniform application of the statutory definition in these cases would produce a benefit going beyond mere symmetry.

Possibly the greatest benefit to be realized from a uniform application of this test would be the elimination of what is at least a tax trap and, perhaps, an invitation to tax evasion. Although the cases clearly demonstrate the husband's double tax liability in antenuptial and certain postnuptial transfers, it seems highly likely that such transfers are not generally recognized by taxpayers as taxable events under the income tax. ${ }^{25}$ Moreover, no case has been found in which the question of the wife's income tax liability has even been considered.

In addition, application of the statutory definition for income tax purposes would eliminate a highly complicated and confused valuation problem. Treatment of the relinquishment of marital rights as a taxable event under the income tax requires not only the immediate valuation of the property transferred and of the rights relinquished but also the assignment of a basis to the forfeited rights. That is, the husband's gain is measured by the difference between his basis in the property transferred and the fair market value of the rights in his estate which are forfeited. The wife, on the other hand, presumably realizes a gain measured by the difference between her basis for the forfeited rights and the fair market value of the property which she receives therefor. As a practical shortcut, the cases evidently assume that the marital rights are equal in value to the property transferred. ${ }^{26}$ Even so, it will

\footnotetext{
${ }^{24}$ See Dunn v. United States, 86 F. Supp. 861, 862 (E.D. Pa. 1949).

${ }^{25}$ Rosenfield, op. cit. supra note $\mathrm{r}$, at $7 \mathrm{r}$.

${ }^{20}$ Commissioner v. Halliwell, $1_{3}$ I F.2d 642 (2d Cir. 1942), cert. denied, $3^{19}$ U.S. 741 (1943); Commissioner v. Mesta, I23 F.2d 986 (3d Cir. I94I), cert. denied, 3 16 U.S. 695, reh. denied, 3 I 7 U.S. 704 (1942).
} 
not always be an easy matter to establish the value of this property. And, as to the wife, what is her basis in the actual or prospective marital rights? There is no apparent logic in assuming, as may in fact be the practice, that her basis is equal to the fair market value of the property which she receives, although this assumption would avoid a tax on the wife. Rather, it could be argued that the wife's basis is her costzero. ${ }^{27}$ Then, if no income tax is assessed upon the wife at the transfer of property in relinquishment of her marital rights, it might be maintained that her basis in that property should be zero and that her entire receipts upon subsequent re-sale should be taxed. ${ }^{28}$

The most perplexing aspects of this valuation miasma would, on the other hand, be avoided in most cases if the statutory full and adequate test of consideration were employed. This test would more likely impel the conclusion that the transfer was a gift, in which case it would be necessary to value only the transferred property in order to establish the gift tax liability. Basis would be a consideration only in that the wife would take the substituted basis of the husband in the property transferred. Gain would be realized only by the wife, and then only upon subsequent re-sale of the property, when its value would be clearly established.

Of course, under this scheme, the income tax burden, if any, would be borne entirely by the wife. This effect could be offset by the horsetrading which characterizes the usual marital settlement. But even if this possibility did not exist, there seems a certain equity in requiring the wife to share the onus of the tax upon her husband's estate to the same extent, practically speaking, as would have obtained had his entire property been sold during the marriage. Moreover, it seems worthy of some consideration that the income tax would be levied at a time when the transfer yielded cash with which to discharge that liability.

Occasional decisions give hope that the current inequities and inadequacies in the taxation of marital property settlements will be corrected

\footnotetext{
${ }^{27}$ It might be argued that the transfers to the wife in return for the relinquishment of her marital rights represent damages for injuries to interests of personality which are not taxable as income to her. See Hawkins v. Com'r, 6 B.T.A. I023 (1927); Sol. Op. 132, I-1C.B. 92 (1922). See also Gould v. Gould, 245 U.S. 151 (1917), where in the absence of an explicit statutory provision to the contrary, the Supreme Court held that alimony was not taxable as income to a divorced wife.

${ }^{28}$ If the wife failed to report the fair market value of the property transferred to her as income, she may be "estopped" to assert that the basis of the property is its fair market value upon a subsequent sale. See Continental Oil Co. v. Jones, 177 F.2d 508 (roth Cir. 1949), cert. denied, 339 U.S. 931 (1950); Artis C. Bryau, 16 T.C. 792 (1951). Cf., however, Bennett v. Helvering 137 F.2d 537 (2d Cir..1943).
} 
by judicial process. For example, the Tax Court recently held in Ina Mae Marshman ${ }^{29}$ that stock transferred by a divorced husband to his former wife in exchange for her promise to re-marry him was acquired by her by gift rather than by purchase. Thus, for capital gains purposes upon subsequent sale, the stock was assigned a substituted basis rather than a higher basis of its fair market value at the time of transfer to the wife. ${ }^{30}$

Yet, it would seem that ameliorative legislation is in order. If it were provided by statute, however, that, for the purposes of all three taxes, the release of dower or curtesy or other marital rights in the transferor's estate shall not constitute adequate and full consideration to any extent, then postnuptial transfers within the purview of section $25 \mathrm{I} 6$ or the Harris case would escape any tax. It is further suggested that the distinctions therein drawn be abrogated and that all postnuptial property settlements be exempted from the gift tax ${ }^{31}$ in reliance, if need be, upon the theory that such a provision would embody the favor accorded a transfer of the identical interests upon dissolution of a marriage which has survived until the death of one spouse through the estate tax marital deduction. ${ }^{32}$

\footnotetext{
${ }_{31}^{30}$ T.C. 269 (1948).

${ }^{30}$ Unfortunately, the Tax Court felt it necessary to distinguish the Farid-es-Sultaneh case on its facts. That is, in the Farid-es-Sultaneh case, the taxpayer had released all marital rights in her prospective husband's estate. On the other hand, in the Marshman case, petitioner gave up no marital rights. Rather, "her right to alimony, as such, was extinguished as a necessary incident of the remarriage but the right to support which the alimony represented was continued by the new status." Id. at 271, 272.

${ }^{31}$ There seems little sense in according certain transfers preferential treatment merely because some lawyer had the foresight to exploit the distinctions embodied in $\S 2516$ or the Harris case. These are, after all, distinctions based on mere form. See Comment, 3 DUKE B.J. I, 9 (1952).

${ }_{32}$ "In light of the auxiliary role of the gift tax there is surely little reason now for imposing any tax on the acceleration of the wife's inheritance by divorce when that inheritance would pass tax free at death in the absence of divorce. The failure to provide some sort of divorce marital deduction to parallel the non-taxability of the division of the community property on divorce can only be explained by legislative oversight." Pedrick, op. cit. supra note 15, at 195-96.
} 